is apparent. Paper was added around the entrance hole in a circular manner. The use of this hole indicates another modification of the usual pattern of the nest-site. Ordinarily, the entrance is at the base of the nest. Most of the paper is of the typical gray color but there are a few segments which are rather brightly colored. A bluish-green strand is apparent in two places, and a reddish-brown strand appears in three different places. We might, ask $\mathrm{Mr}$. Pearce to hazard a guess as to the source of this colored wood!

The interior of the bird-house was completely utilized for the combstructure. Ordinarily, wasps begin with a small nest which consists of a single horizontal comb enclosed in a paper envelope. Enlargement of the nest entails tearing down the inner walls of the envelope. Presumably, this took place within the bird house until the limits of its walls were reached, at which point paper was added to the outside of the house. This colony was thus foredoomed to a limited size by its selection of this nest-site.
Dead wasps, found in the interio of the bird-house after carefully re moving one section of the roof, wer forwarded in April, 1957, to Mr. C. D F. Miller, Dept. Agric., Ottawa, wh kindly identified them as Vespul (Dolichovespula) arenaria (Fabr. Acocrding to Mr. Miler, this specie is widely distributed througout Nort] America in the boreal region and ca be considered as our most commo wasp. These wasps typically build large nest attached to the branch a bush or tree.

Wasps of ancther species (Vespul squamosa (Dru) built a nest in th end of a rolled-up rug suspended i a garage in Florida in Decembes 1952 , according to A. N. Tissot an F. A. Robinson (1954. Some unusue insect nests. The Florida Entomalo gist, 37: 73-92). This observation an others received considerable atter tion because this species had bee formerly supposed to nest under ground. Once again, simple observo tions refute published "facts" an point to the need for further stud of our most common insects.

\title{
Collecting Moths and Butterflies as a Hobb
}

Notes from lectures given by A. O. ASCHIM, Prince Albert, to the Prin Albert Natural History Society

A most rewarding study of nature can be made through collecting moths and butterflies, either as a scientific pursuit or as a simple hobby with a large number of possibilities. This hobby is open to the young and the old, the rich and the poor, the expert and the novice. It is so flexible that it can be a mere pastime, or as serious a study as one wishes to make it. It can be related to other studies of nature, and the moths and butterflies themselves are so numerous and varied, that this hobby is practically unlimited in scope.

The height of a collector's ambition would probably be a scientific collection, correctly classified, neatly mounted and stored. However, this hobby has other interesting facets. Showy specimens mounted under glass make beautiful mounts for home display and for gifts or exchanges. They are also acceptable in serving trays, ashtrays, bronches, ear-rings, etc. The wings of mot? and butterflies may be used to ma artistic designs. You can collect spec mens for photographic purposes as make beautiful transparencies with $35 \mathrm{~mm}$. camera.

\section{COLLECTING APPARATUS}

Collecting nets may be purchas or made at home. It is useful to ha two or three sizes, including a lar net with a fourteen inch hoop and bag about thirty inches long. $T$ handle should be of light, stro wood, not heavier than a broom ha dle. The net itself should be funn shaped but sewn across the bottc about four inches frcm the apex that the ingect can be retrieved wit out injury. One should also have twelve inch net, and for some pi poses an eight inch net. The lens of the bags will be slightly over tw the width of the hoop.

Leno is suitable for the net, $p$ vided a cotton border is sewn arou 
top to take the wear from the al hoop. The hoop should be made $n$ steel wire slightly heavier than wire. The net should be light, balanced and strong.

he best collecting jars are made $n$ wide-mouth pickle jars, etc., ch are not too large and awkward iandle. For large moths and butlies, place in the jar three lumps cyanide of potassium, covering packed sawdust and a layer of roximately three-eighths of an of plaster of paris of the conency of cream poured cver it and mitted to set. The cover should left off till the surplus moisture evaporated. Since this creates a onous gas, the work should be e out of doors. Cyanide of potas$n$ should not be handled withgloves. Three collecting jars are ful, one with three lumps, one $h$ two, and one with one. A small tle of chloroform can be useful in ing large moths in the net but procedure results in very rigid cimens and makes for more diffimounting.

field box should be taken on all ecting trips. When they are to be in this box, the specimens will "papered," i.e. have their wings led up over the back. They might $n$ be put separately into small envelopes, with a note on each elope stating the species, sex, e, locality and collector, in case specimen is not handled again il months later.

apered specimens may be lcosenup and mounted at a later date by ting them in a humidifying jar $r$ night and then mounting them if they were freshly caught. Be cful to avoid mould.

nsect pins of two or three sizes necessary for mounting insects. $y$ have to be purchased from enlological supply companies. Fine, dium and large pins will be needdepending upon the size of ints be mounted. A supply of "setblocks and boards should be de with a groove into which the y of the insect may drop when wings are being dried on the ck. Pieces of glass may be used setting boards to hold the wings hape for drying. One straight and bent "setting" needle simplifies work of mounting specimens.
The hind margin of the front wings should be at right angles to the body. The rear wings should be pulled forward and underneath to the natural position. A "drying" box will hasten the drying of specimens providing it is made to permit artificial heat to enter, but specimens will dry sufficiently well on the blocks or boards without a drying box if given time. Storage cases, cabinets and drawers for perserving collections are very important, but cannot be described in detail in this synopsis.

\section{HOW TO CAPTURE}

The net is the customary method of collecting most moths and butterflies on the wing and its proper use can only bo learned through practice. Awkward manipulation of the net will give disastrous results but with practice one gets the "feel" of the net and comes to handle it quite gracefully.

The second important method of collecting adults is by the use of baits, commonly known as "sugaring." Many different mixtures are used, but in order for the bait to be effective, it must contain enough alcohol to make the specimens sufficiently stupid to be captured; otherwise, they will very easily escape from the bait. Moths respond extremely well to sugaring.

Collectors who wish to do so may collect the eggs and caterpillars and raise them to the adult stage in rearing cages. The eggs of butterflies and moths are beautiful, multishaped and multi-colored. They are laid singly or in groups upon the plant food of the caterpillar and may be found by looking for them there or by capturing a female that is laying eggs. The plant food is very important and its supply must be available for the caterpillar to reach pupa or chrysalid stage. The eggs should be placed in glass cages and the caterpillars removed to screened cages once they are large enough not to crawl through the meshes of the screen. Cages for the caterpillars of moths should have a few inches of earth with a few leaves, etc. in the cage. Caterpillars raised from eggs require no special attention except feeding, but caterpillars captured out of doors should be put in a separate cage and examined frequently 
to make certain they have not been attacked by a parasite. Should any parasite eggs or other signs of infestation be noted on the caterpillar, it should be destroyed immediately as the parasitic flies will hatch and destroy your other caterpillars. Another way of obtaining comparatively "sound" caterpillars is by "beating." This methed is best done by spreading a blanket or tarpaulin under individual trees, and either shaking or hitting the tree to jolt loose any caterpillars feeding upon the leaves. The best trees for this type of collecting are birch, maple, willow and poplar. A ncte should be made at the time of the species of tree, that all caterpillars collected fro birch trees can be fed birch leave and so on.

Caterpillars which have not veloped into pupae by freezeshould be stcred outside until the $f$ lowing season when their natur food may be gathered. Pupae, cocoons or otherwise, may be outside to await their natural "hatc ing" season or brought into the hou which will hasten the emergence as much as three months. Usua this method of collecting permits capture of the adult specimen wh still in a perfect condition.

\section{YOU WERE ASKING?}

Question: What is the proper name for our white-footed, white-bellied mouse? Mrs. D. Sutton, Rocanville.

Answer: Mice of the genus Peromyscus have relatively long tails, large erect ears, large eyes, a gray to reddish-brown color above and white underparts, including the feet. There are two species in Saskatchewan: Peromyscus leucopus and Peromyscus maniculatus. The latter is sometimes called the Deer Mouse (e.g., Burt and Grossenherder, 1952, A Field Guide to the Mammals), but Anderson (1946, Catalogue of Canadian Recent Mammals) places both species under the common name: White-footed Mouse. Since it is difficult to distinguish these two species and since they both have white feet, this practice seems reasonable. According to Anderson, two subspecies of maniculatus occur here, one in northern Saskatchewan and one in the south central region. Peromyscus leucopus is represented in the far southwest. Most cf our "Whitefooted Mice" are therefore Peromyscus maniculatus.-R.W.N.

Question: What is the best way to prepare a bird to send it in to the museum for identification or as a donation?

Answer: In order to arrive in condition suitable for permanent perservation birds (as well as most animals) should either be sent frozen and packed with "dry ice", pickled in a preserving fluid such as alcohol or formaldehyde, skinned and salted, or skinned and stuffed. Specific dir tions may be obtained from an cellent book available for fifty cen Anderscn, R.M. 1948. Methods of c lecting and preserving vertebr animals. National Museum of Cana Ottawa.-R.W.N.

Question: What about band birds? Our locality is parkland tracting a great many species of ne ing birds. My work as a farmer rancher leads to the discovery many nests and the opportunity band lots of birds. I have had a long interest in nature study would find this very interestin Lloyd M. Lohr, Erskine, Alta.

Answer: Banding permits are sued by the Canadian Wildlife $S$ vice in co-operation with the Uni States Fish and Wildlife Service. information write to the Canac Wildlife Service, Department Northern Affairs and Natural sources, Ottawa.-R.W.N.

\section{MAMMAL NOTE:}

The following reports of Sil haired Bats have been received $s$ the publication of the distribu $n$ study in the previous issue of te Blue Jay, (15:38-41, 46):

Record-August or September, 1950, lach, in garage. John Hudson.

Record-Fall, about 1954, Prince Alber id Brooman.

Specisen-Fall of 1952 , Weekes, in $\log \mathrm{n}$. Ronald Hooper. (In personal collect).

Specimen-August, 1955, Raymore, in ;ement. James Luthie. (In personal Jllection.) 